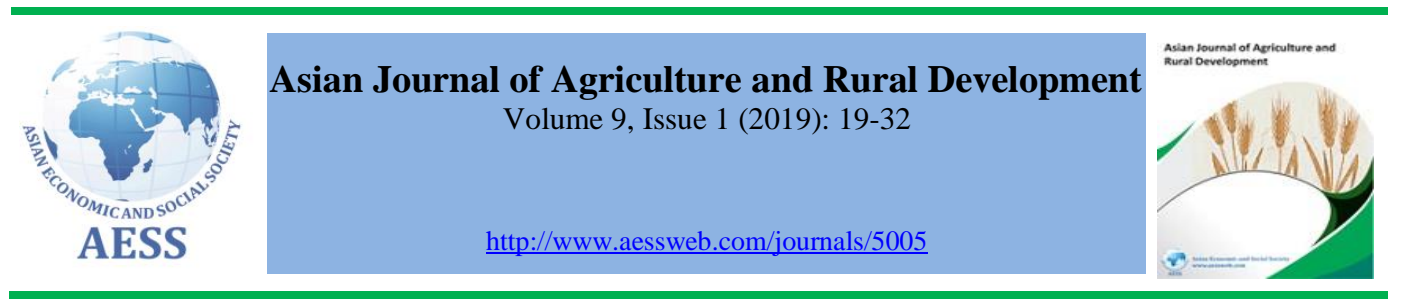

\title{
ANALYSIS OF HOUSEHOLD FOOD SECURITY POLICY: CASE OF FOOD SECURITY VILLAGE PROGRAMME, INDONESIA
}

\begin{tabular}{|c|c|}
\hline $\begin{array}{l}\text { Muhamad } \\
\text { Rusliyadi }^{\mathrm{a}}\end{array}$ & $\begin{array}{l}\text { a Polytechnic of Agricultural Development Yogyakarta- } \\
\text { Magelang, Agricultural Extension and Human Resource } \\
\text { Development Agency, Ministry of Agriculture, Indonesia }\end{array}$ \\
\hline $\begin{array}{l}\text { Azaharaini Bin Hj. } \\
\text { Mohd. Jamil b }^{\text {bo }}\end{array}$ & $\begin{array}{l}\text { b Institute of Policy Studies, University of Brunei } \\
\text { Darussalam, Brunei Darussalam }\end{array}$ \\
\hline $\begin{array}{l}\text { Ratna Tri } \\
\text { Kumalasari }\end{array}$ & $\begin{array}{l}\text { c Agriculture Extension Officer, Agricultural and Food } \\
\text { Security Office, Kebumen Regency, Indonesia } \\
\begin{array}{c}\text { Corresponding } \\
\text { author }\end{array}\end{array}$ \\
\hline ARTICLE HISTORY & ABSTRACT \\
\hline $\begin{array}{l}\text { Received: } 11-\mathrm{Feb}-2019 \\
\text { Accepted: } 01-\mathrm{Apr}-2019 \\
\text { Online Available: } 09- \\
\text { May-2019 }\end{array}$ & $\begin{array}{l}\text { The study analyses a food self-sufficiency village programme (DMP } \\
\text { programme) at household level in the Central Java province of } \\
\text { Indonesia. The data of the DMP programme was collected through } \\
\text { unstructured and semi-structured questionnaires and focus-group } \\
\text { discussions. The survey was conducted in four villages, each } \\
\text { consisting of } 100 \text { samples based on a purposive and clustered } \\
\text { sampling technique. The study compares the implication between } \\
\text { indicators before and after the policy. It was found that the impact of } \\
\text { the DMP programme on the villages was positive. The level of } \\
\text { poverty in each village has been significantly reduced by } 8-40 \% \text { after } \\
\text { the introduction of the programme. The composite food security } \\
\text { analysis at the household level shows the positive impacts of the } \\
\text { programme. }\end{array}$ \\
\hline
\end{tabular}

\footnotetext{
Contribution/ Originality

This research is an original example of the use of food security analysis on a household level and is implemented in one of the government programs based on poverty and food security (food selfsufficiency programme). This research illustrates how a government policy can increase the food security of its people and contribute to poverty alleviation.
}

DOI: 10.18488/journal.1005/2019.9.1/1005.1.19.32

ISSN (P): 2304-1455/ISSN (E):2224-4433

How to cite: Muhamad Rusliyadi, Azaharaini Bin $\mathrm{Hj}$. Mohd. Jamil and Ratna Tri Kumalasari (2019). Analysis of household food security policy: case of food security village programme, Indonesia. Asian Journal of Agriculture and Rural Development, 9(1), 19-32.

(C) 2019 Asian Economic and Social Society. All rights reserved. 


\section{INTRODUCTION}

Food security policy will be a paramount concern for the economic development of many countries for at least the next two decades (FAO, 2006). The rate of increase in population is rising significantly in many countries, but especially in developing countries. Governments are trying to address their food problems, and they need good analysis and implementation of development policies, particularly in rural areas where most people live. Food security analysis, carried out at national and household level is indispensable.

The challenges in food security development in general are linked to high population growth, limited natural resources and shifting functions of agricultural soil, inadequate food sector infrastructure, increased competition with imported merchandise in the marketplace, lack of resources and little market accessibility and the share of poor people (Ahmed et al., 2017; Mukadasi, 2018). Moreover, demand for food per capita increases over time, driven by increased revenue, awareness of health and diet changes, caused by the influence of globalization and various community activities. In Indonesia, poverty and the attainment of food security have been the main problems. Food insecurity is widely experienced in many regions and is positively linked to impoverishment (Weiler et al., 2014).

Rural development aims to achieve food security in a region. It requires integration and collaboration of the aspects of availability, distribution, and consumption of food at a household level. Therefore, a good system is a prerequisite for the realisation of food security by the Food Self-Sufficiency Village Programme (DMP Programme).

The performance of DMP Programme has provided significant impact with some major indicators such as poverty, income and food security in villages. However, rural areas have a classic problem; the participation rate for farmers in the program is low and most farmers in villages face the problem of limited capital resources hindering their success. Policy programs such as DMP Programme need to be effectively developed in collaboration and cooperation with other sectors so that the rural development targets focused on poverty reduction and maintenance of food security at village level can be met (Darwis, 2012).

According to Darwis and Rusastra (2011), the DMP Programme was supported by agricultural and non-agricultural capital programmes, as well as by rural financial institutions. It was facilitated by agricultural extension workers and expert consultants. This programme is directed at several other objectives; raising the availability of foodstuffs, growing the family unit entitlement, recovering the efficiency of food supply and access programmes, enhancing the trade in local food items, raising capital and industry options through the introduction of high-yielding varieties of seeds which agricultural communities in rural areas can develop to increase income, as well as improving the quality of food consumption handling at the household level, and so forth.

\section{MATERIALS AND METHOD}

This research is focused on the existing food security policy in Indonesia with regard to the DMP Programme that has been implemented since 2006. The methodology used in the study was mainly quantitative, but a qualitative approach was also used to enrich the findings of the quantitative study. Primary data were analysed using Microsoft Excel and SPSS. The research site in Java Island has the largest population in Indonesia. Central Java was chosen for this case study because it constitutes $17 \%$ of the population experiencing poverty (CBS, 2011). Secondly, it has many deprived villages as compared to other provinces. Four villages were selected purposively ${ }^{1}$.

\footnotetext{
1 Purposive sampling is also known as judgmental, selective, or subjective sampling, based on the recommendation, of the Agricultural and Food Security Agency in Regency Level
} 
Two villages from Kebumen Regency, namely Kedung Dowo Village in Poncowarno District and Selogiri Villlage in Karanggayam District, and the others in Magelang Regency, namely Madukoro Village in Kajoran District and Candirejo Village in Borobudur District were selected. These villages have been implementing the programme in varying stages with different characteristics and success rates.

Data related to the DMP Programme and extension service were collected using unstructured and semi-structured questionnaire. The survey was conducted in four villages; 100 samples from each, using a purposive and clustered sampling technique based on some particular sample criteria. Criteria of the sample chosen were based on farmer characteristics such as their level of wealth, farmer leader, the village leader, and gender. The purposive sampling technique is a type of nonprobability sampling that is most effective when one needs to study a certain cultural domain with knowledgeable experts within. Purposive sampling may also be used with both qualitative and quantitative research techniques. This type of sampling can be very useful in situations when one needs to reach a target sample quickly, and where sampling for proportionality is not the main concern (Rusliyadi and Libin, 2018).

\section{RESULTS AND DISCUSSION}

\subsection{Food security composite analysis at household level}

Food security is achieved when every household can continuously have access physically and economically to food items (FAO, 1996). Food security should also include availability, accessibility, safety and sustainability. Accessibility represents when every household is able to meet food self-sufficiency, food availability is the average amount of food needs at household level, while food safety emphasize on the quality of food that meets the nutritional needs.

The indicators used in the analysis of food security at the household level are food availability, food access and food consumption or absorption. An indicator of food availability is normative per capita consumption for food production and normative consumption ratio. The ratio indicates whether a region has a surplus production of cereals and tubers. The normative consumption ratio is between the production of food commodity cereals (rice, maize, cassava, and sweet potato) net of the normative population food consumption per day, which is as much as 300 grams of cereals (DKP, 2005).

Food access has indicators that are expressed in the percentage of household poverty, working people and the percentage of those who work less than 15 hours per week. The percentage of those who did not finish elementary schooling, the percentage of households without access to electricity, and the length of roads per square kilometer are indicators which reflect limitation factors in accessing food at the village level (Katarzyna and Raqif, 2017).

Indicators of food consumption or absorption used in the study include; one-year life expectancy of children (nos. /1000), underweight children less than 5 years of age (\%), percentage of illiterate women, percentage of children who are not immunised, percentage of people with access to clean and safe water, percentage of people who reside further than five kilometers from the health center, and the ratio of the people per physician.

The food production is calculated using three years average production (2010-2) of rice, maize, cassava and sweet potatoes, since the main source of food energy comes from cereals and tubers. The pattern of food consumption in Indonesia shows that nearly $50 \%$ of total caloric needs come from cereal crops. For the average net production of cassava and sweet potatoes that are equivalent to rice should be multiplied by $1 / 3$ ( $1 \mathrm{~kg}$ of rice or corn is equivalent to $3 \mathrm{~kg}$ of cassava and sweet potato in terms of calorific value). Per capita net availability of cereals is calculated by dividing 
the total cereal availability by the population. Under the Indonesian consumption profile, the normative consumption of cereals/day/capita is 300 grams (DKP, 2009).

\subsubsection{Availability of food}

The rural lifestyle suggests a low income stream that contributes to vulnerability to food insecurity and to disease, since they cannot afford food prices. In most cases, only rice is being stored as food commodities, harvested in the last season. Only a small amount of harvested rice is sold, so normally people seek for other employment whenever they have free time (Falcon and Naylor, 2005).

The availability of adequate food is an absolute prerequisite for food security; however, it is not a sufficient precondition to ensure food security at the household and individual level. Many efforts have to be made to ensure the availability of food at village level. The key causes of nonavailability of cereals food in some districts include; (1) expansion of oil palm, black pepper, rubber, cashew, and cocoa plantations (2) expansion of open-pit mining areas; (3) swamp areas; (4) upland rice production systems that have low productivity; and (5) non-availability of arable land with respect to population density. In addition, many areas of surplus cereal crops are often affected by disasters due to deforestation, drought or flood. This threatens the sustainability of production levels.

Table 1: Net cereal production per capita per day (G) and normative consumption ratio in villages before and after programme implementation

\begin{tabular}{|c|c|c|c|c|c|c|c|c|}
\hline \multirow{3}{*}{ No Indicators } & \multicolumn{4}{|c|}{ Kebumen Regency } & \multicolumn{4}{|c|}{ Magelang Regency } \\
\hline & \multicolumn{2}{|c|}{$\begin{array}{l}\text { Kedungdowo } \\
\text { Village }\end{array}$} & \multicolumn{2}{|c|}{$\begin{array}{c}\text { Selogiri } \\
\text { Village }\end{array}$} & \multicolumn{2}{|c|}{$\begin{array}{c}\text { Candirejo } \\
\text { Village }\end{array}$} & \multicolumn{2}{|c|}{$\begin{array}{c}\text { Madukoro } \\
\text { Village }\end{array}$} \\
\hline & Before & After & Before & After & Before & After & Before & After \\
\hline $\begin{array}{l}\text { Net Cereal Production } \\
\text { per Capita per Day (g) }\end{array}$ & 521 & 542 & 483 & 502 & 481 & 497 & 465 & 486 \\
\hline $2 \begin{array}{l}\text { Normative } \\
\text { consumption ratio }\end{array}$ & 0.58 & 0.55 & 0.62 & 0.60 & 0.62 & 0.60 & 0.65 & 0.62 \\
\hline
\end{tabular}

Source: Authors' own calculations (2013)

Note: Before: before programme implementation; After: after programme implementation (2013) ${ }^{2}$

Table 1 represents the indicators of food availability at selected sample village level. It showed a positive outcome after the implementation of the DMP Programme. This specifies that, in the first indicator, the net cereal production per capita per day $(\mathrm{g})$ in all villages increased after the implementation of programme. The highest increase was seen in Madukoro (21 grams). The level of food security in the two villages was high. This result shows that the Programme can increase agricultural production, especially in the cereal crops sector. This would be done with the support of training activities and efforts to increase rice productivity through field extension services, that is, provision of assistants in every village.

The normative consumption ratio is a key indicator in the context of food security in a region. Food insecurity of the area is already self-sufficient or does not use this indicator as a reference. The four villages showed that they have a medium surplus. After implementation of the DMP Programme almost all the villages in the Kebumen Regency and Magelang Regency have shown a positive response to a decrease in the value of the normative consumption ratio, which can be interpreted as moving towards surplus food or food self-sufficiency.

\footnotetext{
${ }^{2}$ Classification for normative consumption ratio: > 1.5 - high deficit, 1.25 - 1.50 - moderate deficit, 1.00 1.25 - low deficit, 0.75 - 1.00 - low surplus, 0.50 - 0.75 - moderate surplus, 0:50 - high surplus
} 


\subsubsection{Food access}

Table 2 shows data before and after implementation of the DMP programme. The first indicator; percentage of household poverty, shows that most villages were in a very vulnerable category before implementation of the Programme. After implementation, however, the percentage of poor households decreased significantly, especially in Selogiri (29.8\%). The programme encouraged the development of productive business activities, which increased the income of farmers. This programme is not the only factor contributing to poverty reduction, there are also other programmes, such as social safety assistance, social direct funds for community, rice for the poor and other activities that has encouraged the villages to become independent in food selfsufficiency. The other indirect impact of the DMP programme is the initiation of other programmes in villages. The lowest percentage of poor people (34.53\%) after implementing the programme is found in Candirejo. The villagers, apart from being farmers, are also engaged in tourism activities. Three out of four villages have the potential to become tourism villages because of their natural resources.

Table 2: Food access indicators in villages before and after programme implementation

\begin{tabular}{|c|c|c|c|c|c|c|c|c|c|}
\hline \multirow{3}{*}{ No } & \multirow{3}{*}{ Indicators } & \multicolumn{4}{|c|}{ Kebumen Regency } & \multicolumn{4}{|c|}{ Magelang Regency } \\
\hline & & \multicolumn{2}{|c|}{$\begin{array}{l}\text { Kedungdowo } \\
\text { Village }\end{array}$} & \multicolumn{2}{|c|}{$\begin{array}{l}\text { Selogiri } \\
\text { Village }\end{array}$} & \multicolumn{2}{|c|}{$\begin{array}{l}\text { Candirejo } \\
\text { Village }\end{array}$} & \multicolumn{2}{|c|}{$\begin{array}{c}\text { Madukoro } \\
\text { Village }\end{array}$} \\
\hline & & Before & After & Before & After & Before & After & Before & After \\
\hline 1 & $\begin{array}{l}\text { Percentage of household } \\
\text { poverty }\end{array}$ & 61.54 & 56.46 & 69.42 & 39.60 & 42.36 & 34.53 & 61.14 & 35.56 \\
\hline 2 & $\begin{array}{l}\text { Percentage of people } \\
\text { working less than } 15 \text { hour } \\
\text { per weeks }\end{array}$ & 12.36 & 8.62 & 14.65 & 12.59 & 9.26 & 8.21 & 10.32 & 7.85 \\
\hline 3 & $\begin{array}{l}\text { Percentage of those who } \\
\text { did not finish elementary } \\
\text { schooling }\end{array}$ & 28.75 & 25.67 & 34.56 & 32.20 & 20.21 & 18.95 & 25.87 & 23.23 \\
\hline 4 & $\begin{array}{l}\text { Households without } \\
\text { access to electricity } \\
(\%)\end{array}$ & 3.53 & 3.24 & 3.50 & 3.45 & 1.45 & 1.22 & 1.32 & 1.27 \\
\hline 5 & $\begin{array}{l}\text { The length of road per } \\
\text { square kilometre }\end{array}$ & 2.3 & 4.5 & 2.7 & 3.8 & 4.6 & 6.3 & 1.3 & 1.9 \\
\hline
\end{tabular}

Source: Authors' own calculations $(2013)^{3}$

The second indicator is the percentage of people who work less than 15 hours per week. This is the category of the community who are less productive. Ideally, the average person works at least 35 hours a week, assuming more than five hours a day. Kedungdowo shows a low percentage (3.74\%), before the Food Self-Sufficiency Village Programme was implemented prior to 2013. This situation shows that the duration of Programme, which started from 2009, has been over an extended period and should have reached the stage of self-sufficiency.

\footnotetext{
${ }^{3}$ Note: Before: before programme implementation; After: after programme implementation (2013)

Classification:

Indicator 1: Percent of population below poverty line (\%): $\geq 35$ - Highly vulnerable, 25 - 35 - Vulnerable, 20 25 - Rather vulnerable, 15 - 20 - Quite resistant, 10 - 15 - Resistant, 0 - 10 - Highly resistant.

Indicator 2: Percentage of people working less than 15 hour per weeks (\%): $<50$ - Highly vulnerable, 50 - 30 - Vulnerable, 30 - 20 - Rather vulnerable, 20 - 10 - Quite resistant, 10 - 12:01 - Resistant, 0:01 - 0.0 - Highly resistant.

Indicator 3: Percentage who did not finish elementary schooling ; $\geq 50$ - Highly vulnerable, 40 - 50 Vulnerable, 30 - 40 - Rather vulnerable, 20 - 30 - Quite resistant, 10 - 20 - Resistant, 0 - 10 - Highly resistant Indicator 4: Percentage of Population without access to electricity; $\geq 50$ - Highly vulnerable, 40 - 50 Vulnerable, 30 - 40 - Rather vulnerable, 20 - 30 - Quite resistant, 10 - 20 - Resistant, 0 - 10 - Highly resistant.
} 
When compared to the data of Central Java province, based on the number of hours of work in August 2013, a total of 10.95 million people $(68.60 \%)$ worked over 35 hours per week, while the working population in the study area working less than 15 hours per week reached 1.33 million, equivalent to $8.30 \%$ (CBS, 2013). These findings show that on average, jobless people at village level are higher than the provincial level. Hence, the policy should pay attention to the real condition of the people in the village by creating more job opportunities (Katarzyna and Raqif, 2017).

The third indicator is the percentage people who did not complete elementary schooling. This is an important indicator in this study, since it is concerned with most of the population. The findings show interesting results, that a number of people completed the elementary schooling after the implementation of the Programme. This means that the more they are educated, the more productive they are. Further, the table revealed that only a few villagers are living without access to electricity (below 5\%).

\subsubsection{Food utilization/consumption}

The indicator in food absorption is one-year life expectancy of children (nos. /1000); this is also the number of deaths of infants (0-12 months) per 1,000 live births in the period of one year. These indicators describe the health of the community and success rates of maternal and child health programmes, family planning, as well as environmental and socio-economic conditions. Children with one-year life expectancy in the villages are below $12 \%$ which indicates a good health level and secured food supply at village level. A decreasing ratio of dying children is also observed after the implementation of the Programme.

\section{Table 3: Food consumption indicators in villages before and after programme implementation}

\begin{tabular}{|c|c|c|c|c|c|c|c|c|c|}
\hline \multirow{3}{*}{ No } & \multirow{3}{*}{ Indicators } & \multicolumn{4}{|c|}{ Kebumen Regency } & \multicolumn{4}{|c|}{ Magelang Regency } \\
\hline & & \multicolumn{2}{|c|}{$\begin{array}{l}\text { Kedungdowo } \\
\text { Village }\end{array}$} & \multicolumn{2}{|c|}{$\begin{array}{l}\text { Selogiri } \\
\text { Village }\end{array}$} & \multicolumn{2}{|c|}{$\begin{array}{l}\text { Candirejo } \\
\text { Village }\end{array}$} & \multicolumn{2}{|c|}{$\begin{array}{c}\text { Madukoro } \\
\text { Village }\end{array}$} \\
\hline & & Before & After & Before & After & Before & After & Before & After \\
\hline 1 & $\begin{array}{l}\text { One-year children life } \\
\text { expectancy (nos./1000) }\end{array}$ & 9.21 & 9.17 & 11.92 & 10.41 & 10.39 & 10.25 & 9.63 & 9.21 \\
\hline 2 & $\begin{array}{l}\text { Underweight children }<5 \\
\text { years }(\%)\end{array}$ & 16.70 & 14.1 & 17.34 & 16.65 & 14.87 & 13.4 & 15.93 & 15.46 \\
\hline 3 & Illiterate women $(\%)$ & 15.54 & 14.78 & 16.37 & 16.03 & 20.21 & 19.29 & 23.31 & 21.56 \\
\hline 4 & Children not immunized (\%) & 19.23 & 19.11 & 24.28 & 23.87 & 21.34 & 21.02 & 10.23 & 10.12 \\
\hline 5 & $\begin{array}{l}\text { People with access to safe } \\
\text { water }(\%)\end{array}$ & 80.34 & 89.72 & 87.32 & 83.46 & 69.56 & 72.35 & 85.35 & 90.59 \\
\hline 6 & $\begin{array}{l}\text { People residing more than } \\
\text { five kilometers from the } \\
\text { health center }(\%)\end{array}$ & 6.79 & 6.79 & 10.35 & 10.35 & 16.76 & 16.76 & 9.37 & 9.37 \\
\hline 7 & People to physician ratio & 0.29 & 0.29 & 0.39 & 0.39 & 0.08 & 0.08 & 0.6 & 0.6 \\
\hline
\end{tabular}

Sources: Authors' own calculations $(2013)^{4}$

\footnotetext{
${ }^{44}$ Note: physician $=$ health officer $/$ midwife

Before: before programme implementation, After: after programme implementation (2013).

Classification:

Indicator 2: Percent less toddler nutrition ; $\geq 55$ - Highly vulnerable, 50 - 55 - Vulnerable, 45 - 50 - Rather vulnerable, 40 - 45 - Quite resistant, 31 - 40 - Resistant, $<31$ - Highly resistant

Indicator 3: Percent of women literacy ; $\geq 40$ - Highly vulnerable, 30 - 40 - Vulnerable, 20 - 30 - Rather vulnerable, 10 - 20 - Quite resistant, 05 - 10 - Resistant, $<05$ - Highly resistant

Indicator 4: Infant mortality; $\geq 55$ - Highly vulnerable, 50 - 55 - Vulnerable, 45 - 50 - Rather vulnerable, 40 45 - Quite resistant, 31 - 40 - Resistant, <31 - Highly resistant.
} 
The result shows that most villages are highly resistant (to absorption of food) due to less than $30 \%$ underweight children. The collaboration of DMP Programme with other programmes, such as maternal and child health activities, and neighbourhood health centers in every village, has resulted in low percentages of underweight children in the four villages. The percentage of illiterate women in the villages in Table 3 is in the range $14-23 \%$, which falls under the category of 'quite resistant' (food absorption 10 - 20\%), near to 'rather vulnerable' (food absorption 20 $30 \%$ ). Before the implementation of the DMP Programme, Madukoro recorded the highest percentage for this indicator $(23.31 \%)$. However, after implementation it decreased to $21.56 \%$. The DMP Programme is not aimed at purely educational purposes, rather it aims at providing more intensive assistance to farmers through extension field services which ultimately should contribute to the acquisition of modern farming skills by farmers.

\subsection{Problems and Impacts of Implementing the Food Self-Sufficiency Policy}

\subsubsection{Problem of the self-sufficiency programme in villages}

Social conditions in the study areas are mostly below average with key income coming from agricultural activities which justify the implementation of the DMP programme. The four villages are densely populated and some have more than 5,000 residents. A high population creates job competition, especially in the agricultural sector, because more people depend on one sector. The relatively low formal and informal education level of the people in most villages makes it necessary to undertake greater effort to increase the level of knowledge of the people in order for them to become more productive. Special efforts in the DMP Programme are expected to be incorporated to enable the rural economy to be developed through enhancing people's knowledge of productive activities so as to develop society.

Socio-cultural attitudes of the people in the villages have contributed to the problems of implementing the programme. Low participation in awareness-raising activities has led to a lag in the programme in two villages in the Kebumen Regency. This is partly due to the lack of village officials to publicize the programme to the community. The result is that the sustainability of the programme is difficult to achieve. In Candirejo, the social and cultural aspects involve people's inability to be creative in the utilisation of the available resources. For example, people sell pandan leaf directly to the merchants who visit the village. If the available resources such as pandan leaf were sold in the form of 'handcrafts', this will give added value to the resources and the people could earn more, rather than selling the resources in its 'raw' form. Limited capital availability is also a major problem for many Indonesian farmers. In the programme the government disbursed insufficient funds to meet the capital needs of the society. Agricultural technology used by farmers in the most villages is thus, very rudimentary due to capital constraints yielding low productivity. The low literacy rate is another problem to managing a productive business. This is obviously seen in cultivation, maintenance and post-harvest activities in agriculture, animal husbandry and fishery.

Other problems include the low knowledge of market dynamics and the length of the marketing chain of agricultural products, which are sold at low prices by farmers. The programme connects the farmer activities into affinity groups' engagement in agriculture-based small businesses, livestock, farms and home industry. All four villages under study have very few business networks and strategies for marketing local products to other business partners or investors who can push upwards the rural products to the district level and thus access reliable markets. Lack of transportation facilities also affects market accessibility; this causes farmers to sell their products to merchants who visit the village (middlemen), rather than selling to district-level or regency

Indicator 5: Percent of population with access clean water ; $\geq 70$ - Highly resistant, 60 - 70 - Resistant, 50 - 60 - Quite resistant, 40 - 50 - Rather vulnerable, 30 - 40 - Vulnerable, $<30$ - Highly vulnerable

Indicator 6: Percent of population living; > $5 \mathrm{~km}$ from the health center; $\geq 60$ - Highly vulnerable, 50 - 60 Vulnerable, 40 - 50 - Rather vulnerable, 30 - 40 - Quite resistant, 20 - 30 - Resistant < 20 - Highly resistant. 
traders at higher prices. Another problem is water availability which depends on topography as both villages use water flowing from the hills, and it is very difficult to obtain ground water directly. Dry-land farming practices rely on harvested rain water.

The problem indicators impacting poor/low income farmers' groups are shown in the Table 1A (appendix). The main reason for existing problems from agricultural service institutions' perspective is the lack of understanding of the farmers' challenges which is most significant at the local government level. The difficulty in policy implementation is because the farmers' problems have not been well-explored and understood. This is because the civil servants have very limited time to work in the field. They normally suggest good plans on papers, but fail to implement them due to lack of information on the nature of the problem and possibly lack of commitment and funding too.

The table further shows problems in the implementation of the DMP programme, affecting the performance of farmer's groups in most villages. For example, 'limited access to inputs' makes farmers more dependent on other parties such as brokers/traders and this situation exacerbates the persistence of poverty. Most villages need financial support to implement the DMP programme to be able to meet the farmers' needs. Lack of funds or capital contributes to the inability of farmer groups to invest and become innovative. Other prominent issues are inadequate information, low levels of knowledge and skills, and uncertainty. Access to information and knowledge are important to farmers, as these may help mostly poorly educated farmers to access good prices for their produces, which ultimately solves their problems.

\subsubsection{Impact of the self-sufficiency village programme at village sites}

Table 4 shows the survey results before and after programme implementation in 2013. The data reveal the extent to which the Programme has benefited people in the four villages in terms of social welfare, rural development, and poverty reduction. The income of the people has shown a relative increase in all four villages after Programme implementation. Although it increased at least $5-15 \%$, this still benefits the farmer. The low involvement of farmers and rural communities in the DMP programme was one of the reasons why people's income has been low. The programme needs more farmer involvement or participation so that the impact is more visible and realised.

The main social problem in this research is poverty, because all other indicators (problems) tend to contribute to the context of poverty. The information below is taken and processed from the data of food self-sufficient villages and tabulation was done with village officers in each village and was then adjusted with data from village monographs and Central Bureau of Statistics (CBS) at sub-district level. The level of poverty in each village declined after the introduction of the DMP programme by $8-40 \%$. However, the poverty rate in the villages $(34.5 \%$ to $56.5 \%)$ is relatively higher than the national average in rural areas (14.3\% to $16.0 \%)$ of Central Java province (CBS, 2013). Thus the provincial governments should introduce programmes that focus on empowering rural communities to promote their economic activities. One example is the implementation of the Food Self-Sufficiency Village programme which is complemented by other cross-sectoral programmes.

The programme allocates funding for social assistance targeted at the poor households who participate in farmer groups. With these funds, productive business activities have been implemented, especially in agriculture, livestock, fisheries and small businesses, contributing to households earning income in the community. Stimulation funding of 7143 US Dollars per village from the government is hoping to become a revolving fund scheme for all citizens. The development funds managed by the financial institutions have increased after a few years of DMP Programme implementation. This increase is not very large significantly, except for Madukoro, which has shown a significant level of increase at $78 \%$. The affinity group of the village has 
managed to achieve a good performance. Most of the funds in the villages are allocated to livestock such as goats. At the start, the Food Self-Sufficiency Village programme started with 40 goats and this number has increased to 89 goats during the research period.

The increasing number of institutions for farmers' groups has created a new cluster of affinity groups that can make village economies act independently. This is reflected in the table below, where there is an increase in farmer's groups before and after programme implementation. These groups are important because of their strengthening effect on the community groups. It is part and parcel of building social capital, where a programme is initiated by groups which eventually become self-reliant.

\subsection{Responses to the Food Self-Sufficiency Programme for Poverty Reduction}

\subsubsection{Comparative profile of the programmes in villages}

The findings indicate the variability of implementation in each village. Although the villages are at different stages of implementation, they have virtually the same issues. Poor household involvement in the DMP programme is a major issue in all villages. The procedures outlined in the programme's activities are implemented by former leaders at district level involving over $60 \%$ of poor households for each activity. This initiative can have a direct impact on poor families in gaining their livelihood.

The impacts of the DMP programme on two regencies are different. Kebumen Regency is less responsive to the programme compared to Magelang. The study confirms that the impacts and adoption of the programme in Kebumen are producing lower results compared to Magelang. Local government showed less concern for the programme in Kebumen as compared to Magelang Regency. For example, the local government did not allocate a budget for a replication village in DMP programme in Kebumen Regency. The regency is dependent on the central government for funding. In contrast to this, in the Magelang Regency, local government allocated funds for replication villages for DMP Programme development. In general, local government concern is important in the rural sector development, which depends on leadership quality in terms of paying attention and providing budget allocations.

\subsubsection{Indicators of outcomes of the self-sufficiency village programme}

The changes in the community after the implementation of the DMP programme are shown in Table 5 and they are very impressive. The data show that there is a significant increase in the amount of funds managed by farmer groups. The increase of $78 \%$ in Madukoro is unexpected, because it is a village replication which received social grants that are relatively small compared to other villages. This indicates that the DMP Programme enables augmentation of the local economy through productive activities like animal husbandry (e.g., goats), home industries and fisheries. The result shows that other programmes associated with the implementation of the DMP programme are generating benefits every year. For example, some villages obtained funding of more than a $100 \%$ increase. The collective efforts in implementation of the intensive DMP villages programmes allocated to the Madukoro and Kedungdowo are working well for the endpoint of this research study. 
Table 4: Impact of the self-sufficiency village programme at village sites

\begin{tabular}{|c|c|c|c|c|c|c|c|c|c|}
\hline \multirow{3}{*}{ No } & \multirow{3}{*}{ Indicators } & \multicolumn{4}{|c|}{ Kebumen Regency } & \multicolumn{4}{|c|}{ Magelang Regency } \\
\hline & & \multicolumn{2}{|c|}{ Kedungdowo Village } & \multicolumn{2}{|c|}{ Selogiri Village } & \multicolumn{2}{|c|}{ Candirejo Village } & \multicolumn{2}{|c|}{ Madukoro Village } \\
\hline & & Before & After & Before & After & Before & After & Before & After \\
\hline 1 & $\begin{array}{l}\text { Average income/month } \\
\text { (IDR) }\end{array}$ & $1,457,920$ & $1,681,902$ & $1,393,342$ & $1,647,436$ & $1,467,850$ & $1,687,667$ & $1,290,245$ & $1,589,000$ \\
\hline 2 & Poverty $(\%)$ & 61.54 & 56.46 & 69.42 & 39.62 & 42.36 & 34.53 & 61.14 & 35.56 \\
\hline 3 & $\begin{array}{l}\text { Village aid fund/year } \\
\text { (Million IDR) }\end{array}$ & 100 & 109 & 100 & 111.6 & 100 & 113.78 & 25 & 44.5 \\
\hline 4 & Institutional/farmers groups & 2 & 5 & 3 & 6 & 2 & 6 & 2 & 4 \\
\hline 5 & $\begin{array}{l}\text { Rice yields productivity } \\
\text { (ton/ha) }\end{array}$ & 2.65 & 2.87 & 4.58 & 4.84 & 3.76 & 3.88 & 3.87 & 4.23 \\
\hline 6 & $\begin{array}{l}\text { Livestock population (cows } \\
\text { and goats) }\end{array}$ & 139 & 171 & 245 & 261 & 598 & 805 & 195 & 268 \\
\hline 7 & $\begin{array}{l}\text { Average aid funding from } \\
\text { other sources/year } \\
\text { (Millions IDR) }\end{array}$ & 65.3 & 146.9 & 193.1 & 264.7 & 76.86 & 123.42 & 46.39 & 93.67 \\
\hline 8 & Infrastructure & - & Rice barns and roads & - & Rice barns and roads & - & $3 \mathrm{~km}$ roads & - & $2 \mathrm{~km}$ roads \\
\hline 9 & $\begin{array}{l}\text { Participation of villagers in } \\
\text { the programme }\end{array}$ & 75 & 86 & 68 & 71 & 65 & 72 & 78 & 83 \\
\hline 10 & $\begin{array}{l}\text { Extension officer visit (per } \\
\text { month) }\end{array}$ & 1 & 5 & 2 & 4 & 1 & 6 & 2 & 4 \\
\hline
\end{tabular}

Sources: Authors' own calculations (2013)

Note: Before: before Desa Mandiri Pangan implementation, After: after Desa Mandiri Pangan implementation (2013) 
Table 5: Community gains from the DMP programme

\begin{tabular}{lcccc}
\hline \multirow{2}{*}{ Gains Indicator (\%) } & \multicolumn{2}{c}{ Kebumen Regency } & \multicolumn{2}{c}{ Magelang Regency } \\
\cline { 2 - 5 } & $\begin{array}{c}\text { Kedungdowo } \\
\text { Village }\end{array}$ & $\begin{array}{c}\text { Selogiri } \\
\text { Village }\end{array}$ & $\begin{array}{c}\text { Candirejo } \\
\text { Village }\end{array}$ & $\begin{array}{c}\text { Madukoro } \\
\text { Village }\end{array}$ \\
\hline $\begin{array}{l}\text { Farmers knowledge about the } \\
\text { Programme }\end{array}$ & 87 & 67 & 93 & 78 \\
$\begin{array}{l}\text { Community response to the } \\
\text { Programme in terms of their } \\
\text { actions }\end{array}$ & 76 & 69 & 72 & 87 \\
$\begin{array}{l}\text { Participation of community in } \\
\text { the Programme }\end{array}$ & 86 & 71 & 72 & 83 \\
\hline
\end{tabular}

Sources: Authors' own calculations (2013)

\section{CONCLUSION}

Composite food security analysis at household level shows the positive impacts of DMP programme implementation. This is shown by several indicators, including the rise of $4-7 \%$ in food availability, reduction in poverty by $8-40 \%$, and decrease in people working fewer than 15 hours per week by $10-20 \%$.

In general, the impact of the DMP programme on the villages was positive. The level of poverty in each village has been significantly reduced by $8-40 \%$ after the introduction of the programme. The poverty rate in these villages (34.53\% to $56.46 \%$ ) is relatively higher than the national average in rural Central Java (14.32\% as compared to 15.99\%) (CBS, 2013). This is the justification for selecting the four villages to be the sites of the DMP programme. Thus the expectation is that the national and provincial governments should introduce programmes of this nature in areas or villages where the gap between the poverty level at the grassroots and the national average is high. The programme introduced should be focused on empowering rural communities to enable them to carry out their economic activities. Such empowerment should be complemented by other crosssectoral programmes that should be widely practiced throughout the entire country.

Funding: This study received no specific financial support.

Competing Interests: The authors declared that they have no conflict of interests.

Contributors/Acknowledgement: All authors participated equally in designing and estimation of current research.

Views and opinions expressed in this study are the views and opinions of the authors, Asian Journal of Agriculture and Rural Development shall not be responsible or answerable for any loss, damage or liability etc. caused in relation to/arising out of the use of the content.

\section{Reference}

Ahmed, U. I., Ying, L., Bashir, M. K., Abid, M., \& Zulfiqar, F. (2017). Status and determinants of small farming households' food security and role of market access in enhancing food security in rural Pakistan. PLoS ONE, 12(10), 54-66. DOI: 10.1371/journal.pone.0185466.

Central Bureau of Statistics (CBS) (2011). Indonesia in number book. Statistical Yearbook of Indonesia 2011.

Central Bureau of Statistics (CBS) (2013). CBS Strategies Data, CV. Nasional Indah. Indonesia

Darwis, V. (2012). Food self-reliance movement through the village food resilience program: analyses and constraints. Agricultural Policy Analysis Journal, 10(2), 159-179.

Darwis, V., \& Rusastra, I. W. (2011). Optimizing rural community empowerment through integrating PUAP and Desa mandiri pangan programs. Agricultural Policy Analysis Journal. 9(2), 125-142 
DKP (2005). A food insecurity atlas of Indonesia, 2005. Published by Dewan Ketahanan Pangan in Jakarta, Indonesia.

DKP (2009). Panduan Penyusunan Peta Ketahanan dan Kerentanan Pangan di Indonesia: A Food Security and Vulnerability Atlas of Indonesia (FSVA). Jakarta: Dewan Ketahanan Pangan and World Food Programme.

Falcon, W. P., \& Naylor, R. L. (2005). Rethinking food security for the twenty-first century. American Journal of Agricultural Economics, 85, 1113-1127.

FAO (1996). Rome declaration on world food security and world food summit plan of action. World Food Summit 13-17 November 1996. Rome.

FAO (2006). The State of Food Insecurity in the World 2006. Food and Agriculture Organization, United Nations, Italy.

Katarzyna, B., \& Raqif, T. H. (2017). An innovative approach to food security policy in developing countries. Journal of Innovation \& Knowledge 2, 39-44. DOI: 10.1016/j.jik.2016.01.007.

Mukadasi, B. (2018). Mixed cropping systems for sustainable domestic food supply of the smallholder farming communities in Nakasongola District, Central Uganda. Canadian Journal of Agriculture and Crops, 3(1), 42-54. DOI: 10.20448/803.3.1.42.54.

Rusliyadi, M., \& Libin, W. (2018). Agriculture development programs for poverty reduction evidences from Indonesia and China - comparative study case. Asian Journal of Agriculture and Rural Development, 8(2), 104-118.

Satriawan, B., Dan, O., \& Henny, (2012). Upaya pengentasan kemiskinan pada petani menggunakan model tindakan kolektif kelembagaan Pertanian. Jurnal Ekonomi Pembangunan, 13(1), 96-112. DOI: 10.23917/jep.v13i1.185.

Weiler, A. M., Hergesheimer, C., Brisbois, B., Wittman, H., Yassi, A., \& Spiegel, J. M. (2014). Food sovereignty, food security and health equity: a meta-narrative mapping exercise. Health Policy and Planning, 30(8), 1078-1092. DOI: /10.1093/heapol/czu109. 


\section{APPENDIX}

Table 1A: Matrix showing the problems in general at research village sites for poverty and programme implementation

\begin{tabular}{|c|c|c|c|c|c|c|c|c|}
\hline \multirow{2}{*}{$\begin{array}{l}\text { Problems due } \\
\text { to: } \\
\text { Institutional } \\
\text { issues }\end{array}$} & \multirow[t]{2}{*}{ Problems Indicators } & \multicolumn{3}{|c|}{ Farmer groups } & \multicolumn{2}{|c|}{ Agricultural service institutions } & \multirow{2}{*}{$\begin{array}{c}\text { Village officers } \\
\text { Problems } \\
\text { Dependence on } \\
\text { funds }\end{array}$} & \multirow[t]{2}{*}{ Amoun } \\
\hline & & Poverty & $\begin{array}{l}\text { Problems } \\
\text { Dependence } \\
\text { on Aid } \\
\end{array}$ & $\begin{array}{c}\text { Low investment } \\
\text { capabilities }\end{array}$ & $\begin{array}{c}\text { Function } \\
\text { not optimal }\end{array}$ & $\begin{array}{l}\text { Problems } \\
\text { Lack of understanding } \\
\text { of farmers' problems }\end{array}$ & & \\
\hline \multirow[t]{11}{*}{ Farmer groups } & Limited access to input & & $\mathrm{X}$ & $\mathrm{X}$ & & & & 2 \\
\hline & Imperfect information & $\mathrm{X}$ & $\mathrm{X}$ & $X$ & & $\mathrm{X}$ & & 4 \\
\hline & $\begin{array}{l}\text { Limited availability of } \\
\text { technology }\end{array}$ & & & $\mathrm{X}$ & & $\mathrm{X}$ & & 2 \\
\hline & $\begin{array}{l}\text { Low level of knowledge and } \\
\text { skills }\end{array}$ & $\mathrm{X}$ & $\mathrm{X}$ & $X$ & & $X$ & & 4 \\
\hline & Limitations of capital & $\mathrm{X}$ & & $X$ & & & $X$ & 3 \\
\hline & Moral hazard behaviour & $X$ & & & & & & 1 \\
\hline & Price instability & $\mathrm{X}$ & $\mathrm{X}$ & & & & & 2 \\
\hline & Uncertainty & $X$ & $X$ & $X$ & & $X$ & & 4 \\
\hline & Price taker & $\mathrm{X}$ & $\mathrm{X}$ & & & & & 2 \\
\hline & High transaction cost & $X$ & & $X$ & & $X$ & & 3 \\
\hline & $\begin{array}{l}\text { Poor organisational } \\
\text { management }\end{array}$ & & & $\mathrm{X}$ & $X$ & & $X$ & 3 \\
\hline $\begin{array}{l}\text { Agricultural } \\
\text { service } \\
\text { institutions }\end{array}$ & Limited human resources & & & & $\mathrm{X}$ & $\mathrm{X}$ & & 2 \\
\hline \multirow{3}{*}{ Village officers } & Limited funding & $X$ & & & $X$ & & $\mathrm{X}$ & 3 \\
\hline & Not the decision makers & $\mathrm{X}$ & & & $X$ & & $\mathrm{X}$ & 3 \\
\hline & Number & 10 & 6 & 8 & 4 & 6 & 4 & \\
\hline
\end{tabular}

Sources: Primary data and modified from Satriawan et al. (2012) 
Table 1B: Comparative profile of the programmes in villages

\begin{tabular}{|c|c|c|c|c|}
\hline \multirow{4}{*}{$\begin{array}{l}\text { Indicators } \\
\text { Year start } \\
\text { Type of Program } \\
\end{array}$} & \multicolumn{2}{|c|}{ Kebumen Regency } & \multicolumn{2}{|c|}{ Magelang Regency } \\
\hline & $\begin{array}{l}\text { Kedungdowo } \\
\text { Village }\end{array}$ & Selogiri Village & Candirejo Village & $\begin{array}{c}\text { Madukoro } \\
\text { Village }\end{array}$ \\
\hline & 2009 & 2010 & 2012 & 2011 \\
\hline & Core Village & Core Village & Core Village & Replication \\
\hline $\begin{array}{l}\text { Alocation Aid fund } \\
\text { programme } \quad \text { (million } \\
\text { IDR) }\end{array}$ & 100 & 100 & 100 & 25 \\
\hline $\begin{array}{l}\text { The number of farmer } \\
\text { groups involved }\end{array}$ & 4 & 4 & 6 & 1 \\
\hline $\begin{array}{l}\text { The number of people } \\
\text { involved }\end{array}$ & 75 & 67 & 71 & 35 \\
\hline $\begin{array}{l}\text { Number of poor } \\
\text { household }\end{array}$ & 79 & 513 & 422 & 214 \\
\hline $\begin{array}{l}\text { Percentage } \\
\text { household in the } \\
\text { programme }\end{array}$ & 65.8 & 68.4 & 71.3 & 75.2 \\
\hline $\begin{array}{l}\text { Kinds of activity in } \\
\text { the programme }\end{array}$ & $\begin{array}{l}\text { Livestock } \\
\text { Fishery } \\
\text { Financial } \\
\text { Agriculture } \\
\text { Small Home } \\
\text { industry } \\
\text { Empowerment } \\
\text { society }\end{array}$ & $\begin{array}{c}\text { Livestock } \\
\text { Agriculture } \\
\text { Small Home } \\
\text { industry } \\
\text { Empowerment } \\
\text { society }\end{array}$ & $\begin{array}{l}\text { Goat Livestock } \\
\text { Women } \\
\text { Empowerment } \\
\text { society }\end{array}$ & $\begin{array}{c}\text { Goat Livestock } \\
\text { Empowerment } \\
\text { society }\end{array}$ \\
\hline
\end{tabular}

Sources: Authors' own calculations (2013)

Table 1C: Some impact indicators on the community as a result of the self-sufficiency village programme

\begin{tabular}{|c|c|c|c|c|}
\hline \multirow[b]{2}{*}{ Impact Indicators (\%) } & \multicolumn{2}{|c|}{ Kebumen Regency } & \multicolumn{2}{|c|}{ Magelang Regency } \\
\hline & $\begin{array}{l}\text { Kedungdowo } \\
\text { Village }(\%)\end{array}$ & $\begin{array}{c}\text { Selogiri } \\
\text { Village }(\%)\end{array}$ & $\begin{array}{l}\text { Candirejo } \\
\text { Village (\%) }\end{array}$ & $\begin{array}{c}\text { Madukoro } \\
\text { Village (\%) }\end{array}$ \\
\hline $\begin{array}{l}\text { The number of farmer groups } \\
\text { involved }\end{array}$ & 100 & 100 & 100 & 25 \\
\hline $\begin{array}{l}\text { Increase in number of people } \\
\text { (farmers) involved }\end{array}$ & 15 & 17 & 5 & 32 \\
\hline Increase of programme funds & 9 & 11.6 & 13.78 & 78 \\
\hline Reduction in poverty & 8.25 & 29.8 & 7.83 & 25.58 \\
\hline Increase in income of farmers & 15.36 & 19.75 & 14.96 & 22.33 \\
\hline $\begin{array}{l}\text { Raising aid funds from other } \\
\text { sources }\end{array}$ & 124.96 & 37.079 & 60.57 & 101.92 \\
\hline
\end{tabular}

Sources: Authors' own calculations (2013)

Note: the percentage stated in the Table shows the value after DMP Programme implementation 